\title{
Rebellion of the Righteous: Jesuit Partisanship for Jews
}

\author{
James Bernauer, S.J. \\ Boston College \\ james.bernauer@bc.edu
}

\begin{abstract}
This essay rescues the memory of Jesuit partisanship for Jews and Judaism from a widespread indifference, both scholarly and popular. This memory complicates a long history of Jesuit hostility to Jews and is at the source of a new inter-religious identity for Jesuits. Jesuit rescuers of Jews during the period of the Holocaust crossed traditional borders in embracing a reverence and respect for Jews and Judaism. Both German Jesuit and French Jesuit resistance to Nazism are examined. The Jesuit righteous and resisters formed a spiritual alliance with such important scholars as Augustin Cardinal Bea, Joseph Bonsirven and Henri de Lubac. The witness of the former and the scholarship of the latter prepared the way for the April 24, 1960 petition from the Jesuit Biblical Institute in Rome that requested a declaration on the Jewish People from the Vatican Council, the first institution to make such an appeal to the council fathers. The council's adoption of Nostra aetate with its reshaping of the relationship between Catholics and Jews was one of the most significant outcomes of this rebellion of the righteous.
\end{abstract}

\section{Keywords}

General Congregation 29 (1946) - Kreisau Circle - Mit brennender Sorge - Pontifical Biblical Institute - Righteous among the Nations - Second Vatican Council - spiritual resistance (French, German) - Yad Vashem

Writing about resistance to Nazism during the period of the Holocaust faces potential ambush by an unusual criticism, namely, strong opposition to the drawing of lessons. There are more than a few scholars who advise against

(C) BERNAUER, 2018 | DOI 10.1163/22141332-00502003

This is an open access article distributed under the terms of the prevailing CC-BY-NC license at the time of publication. 
tutelage by this period because they claim that the lessons that are drawn tend to be either singular or vapid: for example, the loss of belief in the Enlightenment's conviction in the perfectibility of the human being; the realization of limitations to progress and the continuing presence of evil. ${ }^{1}$ Peter Novick locates the desire to find lessons in the Holocaust experience in the "hope of extracting from the Holocaust something that is, if not redemptive, at least useful." ${ }^{2}$ He doubts that it can be done. Michael Marrus has devoted an entire book to the question of Holocaust lessons and he fears that the desire to develop such lessons leads to a casual approach to the actual history of these destructive deeds. Although he recommends the study of the Holocaust because it promotes a deeper appreciation of human reality, he concludes: "My principal lesson of the Holocaust is, therefore, beware of lessons." ${ }^{3}$ Of course, there are other voices and these often recommend concrete implications. Peter Hayes draws a clear one: "Beware the beginnings." Once someone yields to a small injustice, he/she is often on a path to excusing great injustice. ${ }^{4}$ Faith in the ability that one is able to make a difference; the need to engage in history and the obligation to be on the side of victims; the duty to recognize basic moral principles and the bonds that unite human beings; the conviction that there is an ultimate meaning to life beyond the present. ${ }^{5}$ The opposition to the drawing of lessons frequently extends to analysis of the "righteous" whom one might have thought would be immune to criticism.

Whenever I have asked my students as well as others to estimate how many "righteous" have been recognized by Israel's Yad Vashem Center, the numbers guessed are almost always ridiculously low. And this is a common viewpoint. Even the chairman of the committee for designating the Righteous, as late as 1974, suggested humorously that planting a tree in honor of each rescuer would hardly lead to a forest of trees on the Avenue of the Righteous at the Yad Vashem campus. ${ }^{6}$ In fact, though, there has long been no space for the number of trees and the names of the righteous are now honored on a wall of remembrance. As of January 1 of 2017, 26,513 righteous have been officially recognized and the long serving director of this program, Mordecai Paldiel, who

1 Peter Novick, The Holocaust in American Life (Boston: Houghton Mifflin, 1999), 239-43.

2 Ibid., 263.

3 Michael Marrus, Lessons of the Holocaust (Toronto: University of Toronto Press, 2016), 153-58, 160.

4 Peter Hayes, Why? Explaining the Holocaust (New York: W.W. Norton, 2017), 343.

5 Ibid., 153-58; William Keeler, "Lessons to Learn from Catholic Rescuers" (Washington, DC: United States Catholic Conference, 1998), 29-30.

6 Moshe Bejski in Rescue Attempts during the Holocaust: Proceedings of the Yad Vashem International Historical Conference (April 8-11, 1974) (Jerusalem: Yad Vashem, 1977), 654-55. 
is now retired, estimates that number is only ten per cent of those who would be deserving of the title.

My own feeling is that the righteous have not yet found their place on the landscape of our moral imagination, despite the publication of the ten-volume Encyclopedia of the Righteous among the Nations, the efforts of some distinguished scholars, and the on-going work of Israel's Holocaust Center. One of those honored by Israel was celebrated a few years ago in a special way on the centennial of his birth, Jan Karski (1914-200o), who gave the moving report in the film Shoah on his visit to the Warsaw ghetto and who spent most of his life as a professor at Georgetown University. But Karski criticized Claude Lanzmann (b.1925), the creator of the film Shoah, for having ignored the rescuers and he said that it was terribly important to remember them for two reasons. First, because they were a morally significant part of twentieth-century history and he even went as far as to put forward a lesson to be learned, namely that institutions, not people, failed during the period of the Holocaust. This is how he expressed it in 1987: "After all, it is not true that the Jews were totally abandoned. Over half a million Jews survived the Holocaust in Europe. Someone helped them: nuns and peasants, workers and underground organizations $[\ldots]$. They [the Jews] were abandoned by governments, social structures, church hierarchies, but not by ordinary men and women."7 The second reason Karski gave for increased remembrance was that the neglect of these rescuers perpetuates the idea that all are or potentially are anti-Semites. The very study of these righteous represents an ongoing critique of anti-Semitism. ${ }^{8}$

If we were to ask why these righteous have been neglected, it may be that so many of our institutions - political, religious, and academic - do not wish to have attention drawn to the opportunities that were available at that time for aiding the needy, opportunities that those institutions did not themselves recognize or seize. And, in a paradoxical way our attention may have been directed away from a consideration of the activity of resisters by the general approach that our culture had taken to World War II. This was the Good War that was won by the Greatest Generation and so the rescuers were absorbed into a broader climate of moral triumphalism. We have come to recognize that this depiction of the war was somewhat mythic, certainly simplistic. Recently, we have seen the publication of Mary Louise Roberts's study What Soldiers Do: Sex and the American GI in World War II France, which emphasized the invasion of Europe by American forces as an erotic adventure that mirrored in a less brutal form the widespread campaign of rape by Russian soldiers in Eastern Europe.

7 "The Mission That Failed: An Interview with Jan Karski," Dissent (Summer, 1987): 334.

8 Ibid., 112. 
Along with those revelations, scholars have given us a better sense of the brutality of the Allied bombing of German cities and its killing of approximately 500,000 civilian occupants. And Americans have long lived with the debate over the use of atomic weapons on Japan. Did this new scholarship draw a shroud over any claims to good activities in general? And has there also been a gender bias among scholars because so many women were rescuers, indeed often being the first person to confront a request for need and the most important channel of communication among the resisters? ${ }^{9}$

Another significant reason for the lack of attention may be the fault of the rescuers themselves because they were so consistently modest about what they had risked. A major analyst of the rescuers' own explanations for what they did asserts that only three per cent of them thought what they did in saving lives was extraordinary. ${ }^{10}$ This self-effacement guaranteed that no huge archive of personal explanations would be left behind and there is reason to think that some of the rescuers themselves wanted to hide their good works out of fear of their neighbors, many of whom were either anti-Semitic or who would have been angry that their personal lives had been put at risk by hiding Jews in their villages. ${ }^{11}$ Even if such an archive had been created, however, would contemporary scholars have had appropriate questions to ask? Elie Wiesel (1928-2016) and the film-maker Pierre Sauvage (b.1944) held a conference in 1984 in which the righteous and various professors were brought together. This is what Sauvage recalled of the event: "We brought all these righteous Gentiles to Washington and in the breaks between sessions the righteous were standing around being ignored by the scholars. No one spoke to them, no one engaged them. How can scholars not be fascinated by these people?"12 Very few historians have even commented upon the rescuers, let alone focused upon them. The masterful works of Saul Friedländer (b.1932), arguably the greatest of contemporary Holocaust historians, do not treat the rescuers even though he himself was rescued.

What is particularly troubling is that this scholarly indifference has shown signs of even developing into an academic hostility toward the righteous. Last

For example, see Katharina von Kellenbach, "Dialogue in Times of War: Christian Women's Rescue of Jews in Hitler's Germany," Women and Interreligious Dialogue, ed. Catherine Cornille (Oregon: Cascade Books, 2013), 70-87.

10 Nechama Tec, "Who Dared to Rescue Jews, and Why?" Resisting Genocide: The Multiple Forms of Rescue, ed. Jacques Semelin et al. (Oxford: Oxford University Press, 2013), 104.

11 See Joanna Tokarska-Bakir, "The Unrighteous Righteous and the Righteous Unrighteous," Dapim: Studies on the Shoah 24 (2010): 11-63.

12 Dara Horn, “The Rescuer," Tablet (January 17, 2012). 
year, the distinguished Brown University historian Omer Bartov (b.1954) took Timothy Snyder's (b.1969) new book, Black Earth, to task for making the rescuers far more saintly than he thinks they deserve to be regarded. He entitled his review "How Not to Write a History of the Holocaust."13 Earlier the philosopher Berel Lang (b.1933) objected to the very term "righteous" because it implied that one's failure to be heroic made oneself unrighteous. He titles his essay "Contra the 'Righteous Gentiles."'14 From another perspective the very influential philosopher Richard Rorty (1931-2007) thought that the rescuers should not be regarded as manifesting a universal love for humanity but rather approached in terms of more parochial interests such as sympathy for a colleague or a nationalistic identification. ${ }^{15}$ In a 1947 interview with the leader of religious affairs for the American military occupation, several German bishops and cardinals seemed indifferent to, if not even critical of, courageous measures by Catholics during the Nazi years. ${ }^{16}$ We are at a curious moment in our current approach to the rescuers. In 2007, a major museum opened in Poland to celebrate the almost seven thousand Polish rescuers honored by Yad Vashem but the museum was criticized for creating the impression that these heroic individuals represented the principal story of Polish conduct during the Shoah. Although there is suspicion of their motives and even claims that the rescuers might be insane for having risked their own lives and that of their families, often for strangers, there is a small counter-current evident in a number of recent published studies that have attempted to do justice to the remarkable people who seem to hear a more urgent voice of conscience than most of us: for example Eyal Press's Beautiful Souls: Saying No, Breaking Ranks, and Heeding the Voice of Conscience in Dark Times, Larissa MacFarquhar's volume Strangers Drowning, and Lisa Dodson's study The Moral Underground. ${ }^{17}$

The Society of Jesus's relationship with the Jews has had a very difficult history and for most of its existence, those with some Jewish ancestry were not allowed admission to the order. Fortunately, the twentieth century largely

13 "How Not to Write a History of the Holocaust," The Chronicle Review (March 11, 2016): $\mathrm{B} 10-\mathrm{B} 12$.

14 Berel Lang, The Future of the Holocaust (Ithaca: Cornell University Press, 1993), 119-125.

15 Norman Geras, "Richard Rorty and the Righteous among the Nations," Journal of Applied Philosophy 12, no. 2 (1995): 151-73.

16 Document 377 in Akten deutscher Bischöfe seit 1945 westliche Besatzungszonen II 1945-1947, ed. Ulrich Helbach (Paderborn: Ferdinand Schöningh, 2012), 1302-11.

17 Eyal Press, Beautiful Souls: Saying No, Breaking Ranks, and Heeding the Voice of Conscience in Dark Times (New York: Farrar, Straus and Giroux, 2012); Larissa MacFarquhar, Strangers Drowning (New York: Penguin Press, 2015); and Lisa Dodson, The Moral Underground (New York: The New Press, 2009). 
witnessed a reversal of this history and it was the German Jesuit Cardinal Augustin Bea (1881-1968) who skillfully directed the deliberations at the Second Vatican Council that led to the promulgation of Nostra aetate, the fiftieth anniversary of which has just been celebrated internationally. This document has been the charter of a new, fraternal relationship between Jews and Catholics. Fortunately, Jesuit theologians and scripture scholars joined with Jewish thinkers to give birth to this document. I believe, though, that one of the principal sources for this changed relationship between Jews and Christians is the neglected witness of Catholic resisters, especially those who have been honored by Yad Vashem. As of now, there are fifteen Jesuits in that group. One of them, Jean-Baptiste Janssens (1889-1964), was chosen to lead the Jesuits in 1946, a choice that might have been interpreted as the potential beginning of a particularly Jesuit examination of conscience of our Society's past conduct toward the Jewish people. That promise was not to be realized for many years.

Any examination of the Jesuit Righteous and resisters should ask, "Why is it important to examine them?" We may identify two interrelated reasons, one which looks toward the past and remembrance while the other looks toward the future and transformation. Hannah Arendt (1906-75) reminds us of the first. In her Eichmann in Jerusalem, she reported on the activity of the German sergeant, Anton Schmidt, which was mentioned at the trial. Schmidt was executed in 1942 for the help he extended to Jews in Poland and he was later honored in Israel as a "righteous." For Arendt, the very ability to recall his courageous deeds undermines any temptation to accept the Nazi regime's declaration of the meaningless of such sacrifice and to have its opponents "disappear in silent anonymity." Arendt contests this ambition: "The holes of oblivion do not exist. Nothing human is that perfect and there are simply too many people in the world to make oblivion possible. One man will always be left alive to tell the story." She goes on to claim that politically "speaking, it is that under conditions of terror most people will comply but some people will not, just as the lesson of the countries to which the Final Solution was proposed is that 'it could happen' in most places but it did not happen everywhere."18

The second reason is directed toward the future and transformation. Perhaps without even realizing it, it is through the pioneering witness of resisters and righteous that we have become interreligious people, believers who do not look down upon the spiritual experience of those who do not share our faith. This is how an official Jesuit document put it years later: "To be religious today is to be interreligious in the sense that a positive relationship with believers of

18 Hannah Arendt, Eichmann in Jerusalem: A Report on the Banality of Evil (New York: Viking Press, 1964; revised edition), 232-33. 
other faiths is a requirement in a world of religious pluralism."19 Such a conviction is a breaking free of the shrunken soul that so much traditional religion imposed. Review of the biographies of Jesuit resisters and righteous show people who think of themselves as ordinary but do not confuse humility with self-negation. They breathe the air of spiritual freedom.

Let me draw a comparison. Despite the great diversity of their activities, these Jesuit righteous become passionate in recognition of the dignity of Judaism and in the saving of Jewish life and thus become crossers of religious boundaries. John Connelly (b.1940) has shown in his magisterial study From Enemy to Brother that the revolution in Catholic teaching on the Jews is especially indebted to the numerous converts to Catholicism from Judaism; these were the border crossers who educated their new co-religionists about the true rich character of Judaism and who emphasized the insight contained in St. Paul's letter to the Romans that, as Connelly expresses it: "Jews remained beloved by God as Jews. They did not need conversion-but the Catholic Church did. ${ }^{20}$ Despite their efforts, however, European bishops, just a few years after the Holocaust, saw no reason to take up Jewish-Catholic relations at the upcoming Vatican Council II: "In over 800 pages of notes from Dutch, Belgian, French, English, Polish and German bishops, not a single suggestion was made to consider Christian-Jewish relations at the Council."21 There were important conversations that overcame that silence, most importantly, the June 13, 1960 meeting between Pope John XxiII (r.1958-63) and the Jewish scholar Jules Isaac $\left(1877^{-1963)}\right.$ who pleaded with the pope that the church reconsider its teaching of contempt for Judaism; the November 26 meeting that same year between Cardinal Bea and the Jewish theologian Abraham Joshua Heschel $(1907-72)$. And then there was the later conversation between the Jesuit Gustave Weigel (1906-64) and Heschel who pressed this question on the Jesuit: "Is it really the will of God that there be no more Judaism in the world? Would it really be the triumph of God if the scrolls of the Torah were no longer taken out of the Ark and the Torah no longer read in the synagogue, our ancient Hebrew prayers in which Jesus himself worshipped no more recited, the Passover Seder no longer celebrated in our lives, the Law of Moses no longer observed in our homes? Would it really be ad majorem Dei gloriam to have a world without

19 "Our Mission and Interreligious Dialogue," in Jesuit Life and Mission Today, ed. John Padberg (St. Louis, MO: Institute of Jesuit Sources, 2009), 548 (\#130).

20 John Connelly, From Enemy to Brother: The Revolution in Catholic Teaching on the Jews 1933-1965 (Cambridge, MA: Harvard University Press, 2012), 187.

21 Ibid., 182. 
Jews?"22 The fact that Heschel used in his last sentence the very motto of the Society of Jesus - "For the greater glory of God" - made the question a direct interrogation of the Jesuit approach to Jews.

Cardinal Bea was undoubtedly the most prominent Jesuit proponent of a new relationship between Catholics and Jews. In November, 1963, Bea addressed the council:

But why is it so necessary precisely today to recall these things? The reason is this. Some decades ago anti-Semitism, as it is called, was prevalent in various regions and in a particularly violent and criminal form, especially in Germany under the rule of National Socialism, which through hatred for the Jews committed frightful crimes, extirpating several million of Jewish people [...]. Moreover, accompanying and assisting the whole activity was a most powerful and effective "propaganda" as it is called, against the Jews. Now it would have been almost impossible that some of the claims of that propaganda did not have an unfortunate effect even on faithful Catholics, the more so since the arguments advanced by that propaganda often bore an appearance of truth, especially when they were drawn from the New Testament and from the history of the Church. ${ }^{23}$

Flowing through this strong statement are several personal currents. We do know that while he was rector of the Biblical Institute in Rome, he became engaged in hiding Jews and non-Jews and protecting them from deportation. ${ }^{24}$ Some of his strongest statements were against accusations of collective guilt for the death of Jesus that were charged to the Jewish people. Did that sensitivity reflect on some level a resistance to the collective guilt being ascribed to the German people for the crimes of Nazism? Another important plank in Bea's public statement is the strong affirmation of all that is "true and holy" in other religions and he calls Catholics to "recognize, preserve and promote whatever is spiritually, morally, socially or culturally valuable in religions different from their own." Jesuits who engaged in scholarly study of the scriptures, as in the case of Cardinal Bea, seem to have developed a far greater appreciation for

22 Abraham Joshua Heschel, Moral Grandeur and Spiritual Audacity, ed. Susannah Heschel (New York: Farrar, Straus and Giroux, 1996), 246.

23 Augustin Bea, The Church and the Jewish People (New York: Harper and Row, 1966), 157.

24 Gefahren, die der Kirche drohen: Eine Denkschrift des Jesuiten Augustin Bea aus dem Jahr 1926 über den deutschen Katholizismus, ed. Klaus Unterburger (Regensburg: Verlag Friedrich Pustet, 2011), 78. 
and became earlier partisans of a new relationship with Judaism itself. And the French Jesuit Joseph Bonsirven (1880-1958) probably deserves pride of place among those scholars because he was so in advance of his time in understanding the dignity and treasures of Judaism. Sadly, assorted interventions from Rome, some of which he attributed to mere anti-Semitism, made him pay dearly for his regard of the Jewish scriptures and religion. ${ }^{25}$ Bonsirven argued that Christianity could understand itself only if it studied its relationship to Judaism rather than to Greek philosophy. He inserted Jesus into his Israeli milieu and acknowledged the vitality of post-biblical Judaism. While not uncritical of Judaism, he never took over a teaching of contempt and he even claimed that God still had a project for Israel that was not reducible to a future belief in Christ. ${ }^{26} \mathrm{~A}$ very important development that testifies to this Jesuit engagement with scriptural studies is the April 24, 1960 petition of the Pontifical Biblical Institute in Rome to the Preparatory Commission for the upcoming Vatican II Council. The petition of the Jesuit staffed institute is the first request by a scholarly body to call for a conciliar declaration on the Jewish people.

\section{French Jesuit Resistance}

The fresh Jesuit approach to the Jewish people that we see represented in the scholarship of Bea, Bonsirven, and the Biblical Institute in Rome was rooted in even deeper soil than scripture study. It flowed also from a spiritual insurrection that took place in Europe, especially in France and Germany, during the years of Nazi control and world war. ${ }^{27}$ We will take up France initially. The term, spiritual insurrection, derives from a remark of Jean-Marie Soutou

25 In a letter (January 19, 1937) to his provincial, Bonsirven attributed an investigation of a lecture he gave to a "shabby anti-Semitism" and said that he could only be criticized for "not having said that the Jews were evil-doers and corrupters." Archives of the Society of Jesus in Vanves, France, Bonsirven file.

26 On Bonsirven, see Laurence Deffayet, "Le rôle du père Bonsirven dans le renouveau du dialogue judéo-chrétien dans l'entre-deux guerres," Revue d'histoire de l'église de France 89, no. 1 (2003): 81-103 and "Le père Joseph Bonsirven: Un parcours fait d'ombres et de lumières," Archives juives: Revue d'histoire des juifs de France 40, no. 1 (2007): 30-44. Also Thérèse Andrevon, "Joseph Bonsirven, S.J.: A Pioneer Theologian of Judaism before Vatican II," in "The Tragic Couple": Encounters between Jesuits and Jews, ed. James Bernauer and Robert A. Maryks (Leiden: Brill, 2013), 333-50.

27 For a pan-European viewpoint on Jesuit activities during the Nazi years, see Vincent Lapomarda, The Jesuits and the Third Reich, $2^{\text {nd }}$ edition (Lewiston, NY: Edwin Mellen Press, 2005). 
(1912-2003), a French layman who joined with the Jesuit Pierre Chaillet (1900$\left.7^{2}\right)$ in the establishment of the group "Amitié chrétienne" in order to assist victims of the Vichy government and of the German occupation of France. In a conversation, Soutou described such activities as a "genuine religious insurrection. ${ }^{28}$ We should do justice to the participation of approximately fifty French Jesuits in this religious insurrection, their description of it as a "spiritual resistance" and, thus, a refusal to reduce their activities to a mere engagement with politics or even a moral resistance. ${ }^{29}$ What was this spiritual resistance? In my view, it embraced at least six features: an intensified self-relation; an immersion in the historical moment; a subversive critique of claims to religious status; a reaching out to other spiritual communities; a direct confrontation with anti-Semitism; and, finally, a commitment to action, especially to the task of saving Jewish life.

First, it entailed for the resister a critical relationship with himself, a fresh self-invention. They were thinkers and actors "without mandate," as Chaillet put it and at a time when the church labored under an omnipresent regime of authoritative orders. ${ }^{30}$ In fact, it was their absence of ecclesiastical mandate that sometimes attracted episcopal denunciation, for these Jesuits were not authorized to speak for the church or to publish materials that had not been approved. One bishop voiced his disdain in 1943 for "the anonymous theologians who had circulated without mandate, handbills of opinion. They are usually styled as 'eminent.' As if the bishops are not theologians themselves." ${ }^{31}$ Some of those mandate-less theologians argue, however, that it was precisely

28 Soutou makes the remark in a conversation with the documentary film maker Pierre Sauvage in his Three Righteous Christians (2011). The figure of fifty French Jesuits (thirty from Lyon province, twenty from the other provinces) is the estimate given by Bernard Comte in his “Jésuites lyonnais résistants," in Les jésuites à Lyon XVIe-XXe siècle, ed. Étienne Fouilloux and Bernard Hours (Lyon: Ens Éditions, 2005), 189-206, here 202. There were approximately three thousand French Jesuits at the time, two thousand of whom resided in France and one thousand in mission territories. Of course, there were many Jesuits who were pro-Vichy and anti-Semitic. See Dominique Avon and Philippe Rocher, Les jésuites et la société française (XIXe-XXe siècle) (Toulouse: Privat, 2001).

29 Henri de Lubac, Christian Resistance to Anti-Semitism: Memories from 1940 to 1944 (San Francisco: Ignatius Press, 1990), 38.

$30 \quad$ J. P. and M. L. Blum, "Le prêtre de demain," a 1965 conversation with Chaillet. In the Chaillet file in Jesuit Archives, Vanves, France. I wish to express my deep gratitude to the Jesuit archivist, Fr. Robert Bonfils for his warm welcome and assistance during a 2010 visit.

31 Bishop Martin of Puy as cited in La Croix (August 1943) as reported in the Office of Strategic Services document "Basis for Accusation of Collaborationism by French Bishops" (February 27, 1945). United States National Archives, OssRG 226, Entry 210, Box 415, folder 3. I am indebted to Dr. Marian St. Onge for giving me access to this document. 
their religious commitment to obedience that sensitized them to what they felt were divine imperatives and that relativized the customary ecclesiastical as well as civil submissions. The statements from the French bishops regarding the respect owed to the legitimate civil authorities did not distract these thinkers without mandates from the discernment of spirits to which they were committed. As the Jesuit Yves de Montcheuil (1900-44) pointed out, "obedience did not mean turning off one's personal conscience."32 Henri de Lubac (1896-1991) captured their energy: "Fessard, de Montcheuil and Chaillet were not dreamers or visionaries; they were profoundly religious men who breathed the great air of catholicity, and their doctrinal work already invited those whose path they were striving to enlighten to a better-informed, more profound fidelity."33 This air of catholicity is a foundational notion for de Lubac and, in his view, for understanding the spiritual insurrection. This air breathes a universal love and has an international outreach that relativizes ethnic and national identities. De Lubac writes of it as a Jesuit charism and holds up as exemplars of it the missionary style of figures such as Matteo Ricci who embraced an oriental mentality and Roberto de' Nobili (1577-1656), "who made himself a Brahmin among the Brahmins." Catholic universality is demanding: "Much more than a mere outward adaptation is required: a whole inner transformation, a real exodus from the secret places of the soul: 'leave your country, your family and your father's house, to go to the place that I shall show you."'34

Secondly, this self-invention was not fabricated in a vacuum but rather in a very concrete grasp of the moment, whether they described that moment as fascist, communist, or totalitarian. Both Fathers Gaston Fessard (1887-1978) and de Montcheuil had attended the 1934 Nuremberg rallies and the former composed his first published work as a response to it and as a plea for universal fraternity. ${ }^{35}$ Chaillet wrote of the spectacle of the triumph of Hitlerism: "We know the disgust and indignation aroused in the civilized world by this shameful hunting down of people treated like unclean beasts."36 De Lubac described

32 Renée Bédarida, Pierre Chaillet: Témoin de la résistance spirituelle (Paris: Fayard, 1988) 202-3. De Montcheuil's remark is cited in Bernard Comte's "Französische Katholische Theologen in der résistance spirituelle," in Vergangenheitsbewältigung im französischen Katholizismus und deutschen Protestantismus, ed. Lucia Scherzberg (Paderborn: F. Schöningh, 2008), 65 .

33 De Lubac, Christian Resistance to Anti-Semitism, 244.

34 Henri de Lubac, Catholicism (London: Burns \& Oates, 1950; original French ed., 1937), $15^{1-52 .}$

35 De Lubac, Christian Resistance to Anti-Semitism, $38-39$.

$36 \quad$ Ibid., $38-39$. 
Nazism as an "anti-Christian revolution" and warned of the neo-pagan cult of the state it proclaimed. Very astutely he observed that the goal of Nazism is "less to destroy Christianity completely than to debase it." ${ }^{37}$ And de Lubac appreciated the weaknesses of Christianity in face of Nazi ideology and practice: "Are there not priests who imagine that a Hitlerian order would favor religion? And have they not gone to the point of spreading word in the presbyterates that, in case of a German victory, a concordat could be signed that would assure salaries to the clergy?" He claimed that the two essential weaknesses were a faith that had become merely habitual and traditional and thus lacked a "principle of life and invention." And the second weakness was that "those very ones who sincerely remained believers were often no longer concerned with Christian virtue and Christian spirit except within the limits of their private life, as if Christianity were deprived of principles for governing the life of either state or business." 38

Thirdly, this spiritual resistance found itself in the situation of criticizing precisely what was being heralded as a return to Christian values in the regime of Philippe Pétain (1856-1951). This regime advocated "order, hierarchy, discipline, and respect for religious and traditional values" and thus took on the "imprint of a moral order and made public expressions of deference to the Church. No Vichy public ceremony was complete without some form of religious observance." ${ }^{39}$ This atmosphere of religiosity seduced many church leaders, including the leader of the Jesuits in France, into a largely uncritical embrace of Pétain and his program..$^{40}$ This is part of the statement that leader, Father Norbert de Boynes (1870-1954), ordered to be read in every Jesuit community and that is dated July 12, 1941:

"Letter to My Superiors (Lyons, April 25, 1941)," in Henry de Lubac, Theology in History (San Francisco: Ignatius Press, 1996), 432 and 430.

38 "Letter to My Superiors (Lyons, April 25, 1941)," in Theology in History, 434, and "Christian Explanation of Our Times (1941)," in ibid., 441-42.

39 Michael Marrus and Robert Paxton, Vichy France and the Jews (New York: Basic Books, 1981), 197-98.

40 The General Assistant for France was Norbert de Boynes who was adamantly opposed to resistance activities. See Avon and Rocher, Les jésuites et la société française XIXe-XX siècles, 153-63. Vincent McCormick (1886-1963) quotes in his diary of April 7, 1943 a lament of de Boynes that conveys the latter's attitude toward France as it suffered from German occupation and Allied attacks: "Well, surely France has deserved this; a nation that for forty years has refused to come back to God" (James Hennesey, "American Jesuit in Wartime Rome: The Diary of Vincent McCormick, S.J., 1942-1945," Mid-America:An Historical Quarterly $5^{6}$ [1974]: 32-55, here 39). 
Here are the directives I feel duty-bound to give you to help you confront the difficulties we now face. There is in defeated France a legitimate government whose leader, universally respected by honest folk for his patriotism, and disinterestedness, is Marshall Pétain. Outside his government there is no other French government [...]. Alongside the established government, there is the fact of dissidence, which works to destroy French unity. What should our attitude, as members of the Company, be? We must first of all accept the established government and obey it in all that is not contrary to the law of God, whatever our own political preferences. In no case may we oppose it, whether within our communities or outside. We must even use our influence [...] to guide souls toward the practice of that obedience which everyone, and above all Catholics, owes to the Head of State. ${ }^{41}$

Both totalitarianism and the Vichy regime reinforced the conviction among resisters that what was at stake in the activity was their very "soul" a motif constantly sounded in their communications. The title of the first issue of Les Cahiers du témoignage chrétien captured the thrust of the resistance campaign "France, guard against losing your soul."

In 1944, de Lubac would explicitly wonder whether the French bishops' administrative concern with the "body" of the church led them to neglect its soul. This charge was contained in the confidential analysis that he had written for Jacques Maritain (1882-1973), who had just been named the ambassador to the Holy See and that is now published in this issue. The document, conserved in Maritain's archives, was published for the first time only in 1992. De Lubac's indictment of the French bishops is severe: they did not have a real sense of the church's independence, of its spiritual authority no matter who is in power; their involvement in administration led them to downplay their evangelical mission; they did not possess a good understanding of Christian doctrine and, thus, were weak in their confrontation with Hitler's propaganda; the church had lost touch with its people, most of whom seemed to support the Resistance while the bishops appeared to favor the Vichy government of Marshal Pétain; some of them were intoxicated with the Pétain cult and de Lubac recalls one bishop who spoke of Pétain's inspiration and another who confessed that, when in the marshal's presence he had to restrain himself from falling to his knees and asking Pétain's blessing; finally, de Lubac judges that the bishops

41 Cited in Jean Lacouture, Jesuits: A Multibiography (Washington, DC: Counterpoint, 1995), 387. See Sylvie Bernay, L'Église de France face à la persécution des juifs 1940-1944 (Paris: CNRs Éditions, 2012), 176. 
tended to think of themselves as functionaries of the state rather than as exercising shared leadership in the international Catholic Church and he compares them very unfavorably with the courage of German bishops. ${ }^{42}$

The fourth trait of this spiritual resistance was its communal character and ecumenical reach. Clergy and laity worked together as did Catholic and Protestants in projects such as Les Cahiers du témoignage chrétien that was itself open to diverse alliances for, as de Lubac pointed out, its editors and writers never claimed a "monopoly on spiritual resistance."43 In the second and third issues there were excerpts, for example, from Karl Barth (1886-1968), from letters of the German bishops to the pope as well as a collective statement from the Dutch bishops, and a statement of the Protestant bishop of Würtemberg. This diversity continued in future issues.

Fifthly, this spiritual resistance was characterized by its frontal assault on racist ideology and on the anti-Semitism justified by it. As far as racism is concerned, the Jesuit Pierre Lorson (1897-1954), who wrote under the pseudonym Lucien Valdor, published a book-length study in French on racism and especially targeted its Aryan version. The copies of Lorson's text were sought after by the Germans during the occupation and destroyed. It seems that only four have survived but fortunately the Library of Congress has guarded one of those. ${ }^{44}$ Lorson drew attention to some of the racist currents that had influenced the Christian milieu, especially in the attitude toward the Hebrew scriptures. He emphasizes the role that God has allotted to the Jews in the history of salvation and God's inspiration of and self-revelation in those writings. ${ }^{45}$ Lorson was not alone in appreciating how racism might infiltrate theological positions and there is a noteworthy alertness to the toxicity of speech against the Jews. De Lubac had warned in his 1941 letter to his superiors that anti-Semitism was "gaining ground among the Catholic elite, even in our own religious houses." 46 Certainly the anti-Semitism of the Dreyfus Affair and of the later Action Française had prepared many Catholics and Jesuits to appreciate the venom of Nazi racism. Of great significance was the Jesuit scholarship that created a

42 "La question des évêques sous l'occupation," Revue des deux mondes (February 1992): $67-82$.

43 De Lubac, Christian Resistance to Anti-Semitism, 143.

44 Lucien Valdor (Pierre Lorson), Le Chrétien devant le racisme (Paris: Editions "Alsatia," 1938). I first learned of Lorson in John Connelly, From Enemy to Brother: The Revolution in Catholic Teaching on the Jews 1933-1965 (Cambridge, MA: Harvard University Press, 2012), 54-55.

45 Lorson, Le Chrétien devant le racisme, 96-97.

46 "Letter to My Superiors (Lyons, April 25, 1941)," in Theology in History, 438. 
new regard for the Jewish roots of Christianity. There was the establishment of the series "Sources chrétiennes" to which Jesuits such as Victor Fontoynont (1880-1958) and de Lubac made major contributions. In addition to Bonsirven's scriptural studies, there were the philo-Semitic writings of Jesuits such as Auguste Valensin (1879-1953) and Michel Riquet (1898-1993). Riquet, first a student and then a friend of Maritain, created a network of friendships with the Jewish community and was probably the best known Jesuit among French Jews. He was chaplain to the Catholic medical students of Paris and, from the beginning of the German government's anti-Semitic persecutions in 1933, he led prayers for the German Jews. He became an adviser to the Resistance and came to witness to his commitment to the protection of Jews with imprisonments in Mauthausen and Dachau concentration camps. ${ }^{47}$

These Jesuits had developed an informed awareness of the unity of the Bible's two testaments and this made them particularly sensitive to Nazi efforts at separating a new from an old Testament. Once again, here is de Lubac in 1941. In speaking of Jesus's critics, he writes that

we must now recognize that his adversaries are often right when they see in many points of his doctrine a contribution owed to Israel and first inscribed in the Jewish Bible. So the defense of Christ would be incomplete if it did not extend to those who prepared for his coming, and to the whole order of things which he himself proclaimed that he had come, not to abolish, but to fulfill. Would the New Testament be understood without the Old? ${ }^{48}$

Jesuits such as these had become partisans of a new relationship with Judaism. ${ }^{49}$ As we have seen Bonsirven may deserve pride of place in the leadership of this campaign because he was so advanced in appreciating Judaism. And this partisanship for the religious witness that had preceded Christ may have opened the way to a broader grasp of the dignity of life itself. De Montcheuil cites with

47 On Valensin and Riquet see Laurent Coulomb, "Hebraei sunt, et ego: Judéité et philosémitisme chez le père Auguste Valensin," Archives juives: Revue d'histoire des juifs de France 40, no. 1 (2007): 58-77 and Sylvie Bernay, "Le Père Michel Riquet: Du philosémitisme d'action lors des années sombres au dialogue interreligieux," Archives juives: Revue d'histoire des juifs de France 40, no. 1 (2007): 100-116. Also see Lacouture, Jesuits: A Multibiography, 38386. In Dachau, Riquet became one of ninety-six Jesuits who spent part of the war years there. On the Jesuits detained in Dachau, see Peter van Gestel, "Jesuits in the Bonds of Dachau," Woodstock Letters 76 (1947): 107-29.

48 Henri de Lubac, "A New Religious Front (1942)," in Theology in History, 482.

49 See La Résistance spirituelle, 194. 
approval an insight from Teilhard de Chardin (1881-1955): "Without this 'love of life,' without this ardor of the soul, this overflowing of vitality, there is no intense religious life, but only apathy and mediocrity."50 Was it this love for life that led these Jesuits we are discussing to a heightened empathy for those who were being deprived of that gift of life? And did not that empathy give witness to their overcoming of dualisms, that of time versus the eternal, nature versus the supernatural, the spiritual versus the worldly, the blindness of Jews opposed to the vision of Christians?

The sixth feature in this spiritual insurrection was that it was oriented to action and it contributed to a very effective rescue of Jewish people from the jaws of Nazi murder; seventy-five per cent of French Jews survived the Holocaust. ${ }^{51}$ And was not this activity of rescue one of the principal roots for the new relationship that developed between Christianity and Judaism and of the theological reflection that articulates it? Let us look at some of this effective practical action.

Chaillet is an imposing figure and, as founder and leader of Les Cahiers $d u$ témoignage chrétien he has been called the "conductor of the clandestine orchestra" of the spiritual resistance and a "hero in the armies of spirit." ${ }^{2}$ Trained as a specialist in modern German theology, he had forged an international sensibility by living in six different European countries as well as in northern Africa and the Middle East. During his time in Austria he saw Nazi brutality up close and his reflections on Austria's suffering became one of his first books. ${ }^{53}$ He claimed that the military defeat of France should not lead to collaboration and successive capitulations. ${ }^{54}$ In the special issue of Les Cahiers du témoignage chrétien on anti-Semitism in June, 1942, Chaillet writes that Nazi propaganda has created the so called "Jewish problem" and argues that antiSemitism is actually "treason" that should be punished because it is trying to divide the French people after the military defeat of 1940. He explicitly rejects silence and what he calls a false prudence in the face of Nazi hatred of the

50 Yves de Montcheuil, For Men of Action (South Bend: Fides Publishers, nd), 111. De Montcheuil was executed by the Nazis on August 10, 1944 for the crime of pastoral care for members of the French resistance. For an examination of his theology of action, see David Grumett, "Yves de Montcheuil: Action, Justice, and the Kingdom in Spiritual Resistance to Nazism," Theological Studies 68 (2007): 618-41. Bernay, L'Église de France face à la persécution des juifs, 10, 17.

$5^{2}$ Bédarida, Pierre Chaillet, 187; Le Croix (May 24, 2000): 26.

53 See the document "Les Racines spirituelles de Pierre Chaillet"; no author in Pierre Chaillet dossier, Department of the Righteous, Yad Vashem, Israel. His book, L'Autriche souffrante was published in 1939 .

$54 \quad$ Les Cahiers du témoignage chrétien, 312. 
Jews: "Christians, we have the urgent duty to witness before all of our brethren the following of the essential principles of our faith and proclaim that antiSemitism is incompatible with Christianity." 55 In the next issue of Les Cahiers du témoignage chrétien (August, 1942), Chaillet denounces compromises with Nazism and asserts that National Socialist neo-paganism perverts God's created order and, thus, forces the church to repudiate it or, failing to do so, warns that the church itself will die of suffocation. ${ }^{56}$ Twenty years after the end of the war, Chaillet preaches at Notre Dame a sermon both celebrating the Christian martyrs of Nazism and condemning the broad compromise with totalitarianism by so much of Christianity during the occupation. ${ }^{57}$ Although Chaillet will probably be most remembered for his establishment of Les Cahiers du témoignage chrétien, his saving of Jewish life is his most significant theological act. While he provided Jewish refugees with forged papers and helped them enter Switzerland, his greatest deed was the rescue of 108 Jewish children, an act for which the French government confined him to a psychiatric hospital. Unfortunately, when he was to be honored for his courage in 1957 in New York by the Anti-Defamation League, the Jesuit superior general forbade his attendance at the New York ceremony for reasons that have never became public. Would his attendance have drawn attention to the collaboration of higher religious authorities? ${ }^{58}$ When Yad Vashem declared him a Righteous among the Nations on July 15, 1981, it was a posthumous recognition that followed a few months after the naming of a busy square in Paris as Place Père Chaillet.

\section{German Jesuit Resistance}

What is striking about the German Jesuits is the diversity of their activities and the constant harassment that several hundred were subjected to by the Nazi authorities. Frequent Gestapo reports on the Jesuits emphasized their influence and the threat their activities posed to the National Socialist regime, especially as a result of their work in the education of the young. Spies regularly attended the sermons of Jesuits and wrote up reports on their frequent

\footnotetext{
55 Ibid., 319. Emphasis in the original.

56 Renée Bédarida, Les Armes de l'Esprit: Témoignage chrétien (1941-1944) (Paris: Les Éditions Ouvrières, 1977), 312, 319, 323.

57 Sermon at Notre Dame on November 7, 1965. Pierre Chaillet dossier, Department of the Righteous, Yad Vashem, Israel. His book was L'Autriche souffrante, which was written in 1938.

$5^{8} \quad$ As Bédarida speculated in his Pierre Chaillet, $286-88$.
} 
denunciations of racial teaching, their criticisms of Hitler, and their spreading of a spirit of defeatism. ${ }^{59}$ The preachers were regularly brought in for interrogations and, in many cases, for far worse. For example, there is the case of Fr. Josef Spieker (1893-1968) who was the first Catholic priest to be thrown into a concentration camp and who was featured in a study by Eric Johnson. ${ }^{60}$ Spieker divided his time doing pastoral work between Cologne and Berlin where he publicly preached against the Nazi regime. Under regular surveillance by the Gestapo, he was arrested and put in a concentration camp but Spieker did not feel the support of the church authorities for his anti-Nazi activities. It seems that Superior General Włodzimierz Ledóchowski (in office 1915-42) pleaded to the Nazi government for his release and in a letter of November 7, 1935 promised that the "heads of the order would take pains to insure that Father Spieker, once he is let go, would be sent out of the country and that outside of Germany he would not involve himself in anti-German activities." Eventually Spieker was released and assigned to Chile where he was reprimanded by Society authorities for some of his anti-Nazi lectures there. He was a heroic figure and Johnson's judgment on him poses a question about Jesuit strategy at the time: "Fr. Spieker's banishment to Chile most likely saved his life, but it was a great loss to Germany."61 If Spieker was prevailed upon to leave Germany, there were other Jesuits who debated whether to flee but decided to stay. One of these was the aristocrat Georg von Sachsen (1893-1943). He wrote in 1936 to the Jesuit superior general that Nazi propaganda had made Germany a spiritually unhealthy region but by staying he could witness to Christian values and do some good, including the providing of assistance to Jews for escape from Germany. ${ }^{62}$ And then there were Jesuits who fled Germany to save their lives and continue their denunciations of Nazism from abroad. Fr. Friedrich

59 Perhaps the single most important document revealing Nazi attitudes toward Jesuits and their influence is the extensive 1937 report of the Gestapo. It has been published in Berichte des SD und der Gestapo über Kirchen und Kirchenvolk in Deutschland 1934-1944, ed. Heinz Boberach (Mainz: Matthias-Grünewald-Verlag, 1971), 242-73. For other examples, see Meldungen aus Münster 1924-1944, ed. Joachim Kuropka (Münster: Verlag Regensberg, 1992), especially 420 and 493-94; and Die Juden in den geheimen NS-Stimmungsberichten 1933-1945, ed. Otto Dov Kulka and Eberhard Jäckel (Düsseldorf: Droste Verlag, 2004), 125 (report no. 100).

6o Eric Johnson, Nazi Terror: The Gestapo, Jews, and Ordinary Germans (New York: Basic Books, 200o), 196-212. Also see Spieker's memoir Mein Kampf gegen Unrecht in Staat und Gesellschaft: Erinnerungen einer Kölner Jesuiten (Köln: Verlag J.P. Bachem, 1971).

61 Ibid., 546 and 212.

62 Clemens Brodkorb and Christopher Kentrup, Georg von Sachsen:Kronprinz, Priester, Jesuit (Heiligenstadt: Verlag F.W. Cordier, 2004), 58-6o. 
Muckermann (1883-1946) was probably the best known Jesuit opponent of the Nazis but also a sharp critic of what he regarded as the church's lack of courage in confronting the Hitler government. He challenged the German bishops in 1934: "Why, the people now ask and the entire world will soon enquire, does the Church not move against the Nazis with the same energy which it found [in its attacks] on the Bolsheviks and Socialists?"63 Forbidden by the Nazis to speak or write publicly, he fled Germany in 1934 and began publishing the antiNazi journal Der deutsche Weg while he was in exile. Muckermann died in Switzerland. Although his personal courage cannot be doubted, he seems to have shared in some of the anti-Semitic attitudes that were common in German culture in the period between the world wars. After World War I, he had been imprisoned by the Communists and, as a consequence, he frequently put Jews and Communists together as persecutors of religion. Although Muckermann denied that he was an anti-Semite, he did articulate his anxiety regarding the threat to the Christian way of life that he believed was presented by Jewish influence in cultural and finance circles. ${ }^{64}$

Another very well-known figure was the Munich preacher Rupert Mayer (1876-1945). A visitor to the Sachsenhausen Concentration Camp Memorial outside of Berlin will find there a picture on the wall in a prison cell of the now Blessed Rupert Mayer. Decorated for his bravery in World War I, he preached against any compatibility of National Socialism and Christianity. He was arrested and imprisoned several times and one of those arrests motivated the archbishop of Munich, Cardinal Michael Faulhaber (1869-1952), to preach a very forceful sermon on July 4, 1937, in which he said that the arrest of Mayer was a warning sign that Germany had entered into a new Kulturkampf with the aim of destroying Catholicism. ${ }^{65}$ His various imprisonments broke Mayer's health with the result that he died in 1945 shortly after the end of the war.

63 Cited in Peter Godman, Hitler and the Vatican: Inside the Secret Archives That Reveal the New Story of the Nazis and the Church (New York: Free Press, 2004), 36. See his earlier strong response to Hitler's assumption of dictatorial powers in "Die Würfel sind gefallen," Essener Volkszeitung (March 26, 1933), reprinted in Hubert Gruber, Katholische Kirche und Nationalsozialismus 1930-1945 (Paderborn: Ferdinand Schöningh, 2006), 35-38.

64 See Hubert Gruber's study Friedrich Muckermann, S.J.: Ein katholischer Publizist in der Auseinandersetzung mit dem Zeitgeist (Mainz: Matthias-Grünewald-Verlag, 1993), especially 107-18. Muckermann's memoirs were published posthumously as Im Kampf Zwischen Zwei Epochen: Lebenserinnerungen, ed. Nikolaus Junk (Mainz: Matthias-GrünewaldVerlag, 1973).

65 Sermon of Cardinal Faulhaber in Gruber, Katholische Kirche und Nationalsozialismus 1930-1945, 348-53, here 351 . 
Mayer was beatified by Pope John Paul II (r.1978-2005) on November 3, 1987.66 Nazi camps were to become prisons_-or death camps—-for many Jesuits. Indeed the Jesuits in Dachau formed a functioning community with ninety-six Jesuits in residence from 1941 to 1945. Of these thirty-one died-twenty-four Poles, three Germans, two Dutch, one Frenchman, and one Belgian. This international community of Jesuits "talked about world problems" and tried to "concentrate on the fundamental ideals of St. Ignatius and his spirituality, for these ideals brought home to us again and again that we were not living in vain, that, confined though we were within barbed and electrified wire, with machine-guns pointing on us day and night, we were not cut off from the spiritual front of Christ's army." ${ }^{\prime 2}$ That army included many martyred and imprisoned German Jesuits. ${ }^{68}$

Just after Hitler's coming to power the Jesuit Jakob Overmans (1874-1945) wrote an extraordinary review essay in which he argued for the significant place that Jews occupy in German and European culture and of the danger of a "narrow nationalism." He claims that for the "national German it is of the utmost importance to be also supernational European." He even points to the legend of Ahasuerus, the Wandering Jew, and praises him as a "serious preacher, a good Samaritan" and as someone whose "restlessness arouses often more sympathy than scorn." He continues: "Those who marginalize the value of foreign peoples, have not penetrated the foundations of their own culture, and no one, who reads the Jewish Yearbook, seeing famous personalities from page to page cannot deny that Jews, aside from their great accomplishment in keeping the ethical monotheism in the pre-Christian centuries, have also made considerable contributions to the material advancement of humanity in trade and industry, in the sciences and the arts." 69 This is an extraordinary essay because it exhibits a Jesuit's freedom from any traditional "asemitism" by celebrating Jewish presence and achievement as well as by embracing a trans-national European cultural identity. That vision was to become a sacred cornerstone of the postwar renewal of Europe. Overmans's article directs us to an appreciation

66 See Roman Bleistein, ed., Rupert Mayer, S.J.: Leben im Widerspruch (Frankfurt am Main: Verlag Josef Knecht, 1991).

67 Peter van Gestel, S.J., "Jesuits in the Bonds of Dachau," Woodstock Letters 76 (1947): 107-29, here 111. A novel based upon the experience of the priests in Dachau was published in 2012: William O'Malley, The Place Called Skull (Indianapolis: Dog Ear Publishing).

68 For brief biographies of these, see Rita Haub, Es fordert den ganzen Menschen: Jesuiten im Widerstand (Munich: Echter, 2007) and Helmut Moll, ed., Zeugen für Christus: Das deutsche Martyrologium I (Paderborn: Ferdinand Schöningh, 1999), 779-97.

69 Jakob Overmans, “Der gute Europäer und der ewige Jude," Stimmen der Zeit 125 (July 1933): $271-74$. 
of the frequent boldness of Germany's best known Jesuit journal of culture Stimmen der Zeit, which was remarkably able to operate until as late as April, 1941 when the Gestapo shut down the Munich based review for the rest of the war. Although it was under continual investigation and regular harassment, the journal survived because its remarks on government policy were subtle and it presented itself not as a political review but rather as a scholarly journal of ideas. But it was a rare voice of criticism in Germany and even dared to confront the government by expressing its shock at the brutality of the Roehm purge of 1934 and by "asking whether the Nazis planned to make a habit of brutalizing any and all who did not share their opinions." ${ }^{70}$ Less directly, the Jesuit Max Pribilla (1874-1954) could write on the superiority of Aristotelian political philosophy over Platonic forms that subordinated the individual to the state and it was clear what his target was. He could also warn of nationalisms that became religions. The Jesuit Anton Koch (1898-1978) directly confronted Nazi religious movements such as the "German Christians" as well as their ideological source, the Nazi leader Alfred Rosenberg (1893-1945). He claimed that, contrary to propaganda, such movements were an abandonment of Germany's religious heritage and contrasted a Nazi "fog" world with the survival of the church: "For the last four hundred years, men have at least once every century declared her dead-but she lives. Those who declared her dead have climbed into their graves - the Church, however, lives. She is grounded in fact, in Godgiven facts." In 1934, Jesuit historian Hugo Rahner (1900-68) pointed to the failure of Sparta as a warning against German fascination with Greek models and racial purity. ${ }^{71}$

Perhaps the most important German Jesuit writings, however, were not those published in journals and books but rather those that were composed for ecclesiastical authorities with advice on how the church might confront the Nazi state. The incompatibility of National Socialist ideology and the Christian faith had become obscured by several factors: the German episcopacy's 1933 lifting of its earlier prohibition on association with the Nazi party; the 1933 concordat between Hitler's regime and the Vatican; and the welcome accorded Hitler's coming to power by several prominent Catholics, including some prominent theologians. ${ }^{72}$ Requests had been made of the German bishops and the Vatican that there be clear condemnations of Nazi doctrines that were obviously opposed to Christian faith. Eventually, Pope Pius XI (r.1922-39) would release

\footnotetext{
$70 \quad$ Martin F. Ederer, "Propaganda Wars: Stimmen der Zeit and the Nazis, 1933-1935," The Catholic Historical Review 90, no. 3 (July, 2004): 456-72, here 471.

71 Ibid., 467 .

72 See Robert Krieg, Catholic Theologians in Nazi Germany (New York: Continuum, 2004).
} 
an encyclical Mit brennender Sorge (With burning concern) that was read from the pulpits of Germany on Palm Sunday, 1937. It was the strongest statement ever issued by the Vatican against the Nazi regime. The encyclical came, however, two full years after the Holy Office in the Vatican had assigned to several Jesuits (Franz Hürth [1880-1963], Johannes Baptista Rabeneck [1874-1960], and Louis Chagnon [1895-1944]) the task of drawing up a list of Nazi beliefs that should be condemned as violating the Christian faith and the moral law. This delay has been judged scandalous in the eyes of some and yet it did reflect the traditional slow pace of Vatican deliberations. ${ }^{73}$ The papal encyclical was far less confrontational that the two documents that the Jesuits had drawn up $(1935,1936)$ and what is striking about their documents, in the light of asemitism, is their unrelenting stress on the unity of the human race. ${ }^{74}$ To be formally condemned by the church in the first document are these propositions: "Mankind, which consists of races so different from one another, is not one in origin or descent from the same common ancestors." "The good of the race, on this earth is surpassed by no other good but surpasses all other goods always and in every respect." "Any mixture of blood with a foreign and inferior race, in particular a mixture of the Arian with the Semitic race, is, by reason of that mixture alone, a most heinous crime against nature and marks a grave fault in the conscience."75 The documents contain strong denunciations of racism, "idolatrous nationalism," totalitarianism, and militarism. To be condemned are these beliefs: "Its own glory and power are sufficient reasons for the nation to proclaim and follow the principles of 'expansionism' and to subject other nations and their territory to itself in whole or in part with armed force." "The glory achieved by victory in armed struggle is considered greater, and is indeed sufficient reason for the state, when a conflict arises between nations, to provoke wars and armed conflicts, in contempt of peaceful negotiations capable of resolving the conflict and satisfying its own claims." ${ }^{n 6}$ The 1936 document adds a condemnation of Communism to a greatly abridged version of the 1935 statement. Mit brennender Sorge preserves many of these condemnations and stresses the connection of Christianity and Judaism in, for example, these statements: "The sacred books of the Old Testament are exclusively the word

73 See Thomas Brechenmacher, "Pope Pius XI and the Persecution of the Jews in Nazi Germany, 1933-1939: New Sources from the Vatican Archives," Bulletin 22, no. 2 (November, 2005): 17-44.

74 Both documents are published as appendices to Godman, Hitler and the Vatican, 172-99.

75 "The Holy Office's First Proposed Condemnation of National Socialism (1935)," in ibid., $177,181$.

76 Ibid., 175 . 
of God, and constitute a substantial part of His revelation." "Whoever wishes to see banished from church and school the Biblical history and the wise doctrines of the Old Testament, blasphemes the name of God, blasphemes the Almighty's plan of salvation [...] he denies his faith in the true Christ who took his human nature from a people that was to crucify Him."77

Among the most forceful opponents of the Nazi government was the leader of the German Jesuits based in Munich, Augustin Rösch (1893-1961). In 1941, in response to the increasing persecution of religious orders, especially the Jesuits, Rösch helped found an often overlooked group, the Committee for the Affairs of Religious Orders of the Bishops Conference, which has had an excellent study devoted to it. ${ }^{78} \mathrm{~A}$ principal objective of the group was to challenge the weakness of the Catholic bishops in facing up to the Nazi government. This challenge was directed especially at the leader of the German Catholic bishops, Cardinal Adolf von Bertram (1859-1945), who was the single greatest obstacle to any effective confrontation with that government. The committee soon became associated with resistance circles, the Kreisau Circle in particular. Named after the estate of one of its leaders, Helmuth James von Moltke $(1907-45)$, an international lawyer from a family of great prominence, the Circle embraced a program for the post-Nazi ethical foundations of the German state, one that would be rooted in a recognition of human rights.

Perhaps the most important statement Rösch collaborated in writing was a proposed declaration by the bishops on human rights in November, 1941, that would defend the church, criticize the government, and clearly identify the rights that were under assault. ${ }^{79}$ Although Bertram sabotaged it and few Catholics at the time learned of it, the statement is significant as a revelation of the strong conclusions that some such as Rösch had come to and their willingness to publicize them even in the midst of war. After expressing concern for the military dead and wounded, the statement claims that there is also a "spiritual battle" over people's immortal souls that is taking place. It defends the church from the two charges that it is soft on communism and that it has weakened confidence in the national leadership. The Nazi government's 1939 treaty with the Soviet Union is contrasted with the long history of denunciations

77 "On the Present Position of the Catholic Church in the German Empire" ("Mit brennender Sorge," March 14, 1937), The Catholic Mind 35, no. 9 (May 8, 1937): 185-208, here 190.

78 Antonia Leugers, Gegen eine Mauer bischöflichen Schweigens: Der Ausschuß für Ordensangelegenheiten und seine Widerstandskonzeption 1941 bis 1945 (Frankfurt am Main: Knecht, 1996).

79 "Entwurf eines gemeinsamen Hirtenworts" (November 15, 1941) in Augustin Rösch, Kampf gegen den Nationalsozialismus (Frankfurt am Main: Knecht, 1985), 120-33. 
of communism by the papacy and the German episcopacy. Responding to the second charge, the letter claims that the causes for the weakening of the people's trust is conduct that seems to imitate that of Bolshevism; if the war is being waged against atheistic Communism, why is the war against God and the church growing stronger in Germany itself? The statement went on to attack the Nazi government for having systematically violated the terms of the 1933 concordat: large numbers of churches have been closed; pastoral care of Catholics has been frustrated; Catholic civil servants are regarded as unreliable; parental rights are violated with the closing of religious schools; Christian beliefs and moral teaching are attacked, priests arrested and religious orders hindered in their activities. Finally, the document defends the rights and laws that "must remain the pillars of Christian and all human culture." ${ }^{80}$ Four are explicitly developed. There is the right to private property that the state violates in its confiscation of church structures. There is the "natural right to the protection of truth and honor," a right violated when Christians are labeled state enemies and traitors. There is the "natural right of personal freedom" even as thousands of men and women languish in the cells of the secret police. This protest is made because the "rape of personal freedom goes against the dignity of man as the likeness of God." Finally there is a "natural right to life" and so the killing of the mentally ill is murder. "God alone is the master of life and death." No one's life is safe if the commandment is not regarded as inviolable: "Thou shalt not kill." ${ }^{11}$ German Catholics were not to hear this reminder of that commandment from their bishops just as their nation plunged into unrestrained mass murder and genocide.

In addition to Rösch, whom von Moltke once celebrated as "Catholicism's strongest man in Germany," two other Jesuits would play important roles in the Circle, Delp and the very influential but often underestimated Lothar König (1906-46).82 Rösch's statements reflected an accurate knowledge of what was taking place within Germany and its controlled territories. In a November, 1941 letter to the leader of the Jesuits in Rome, he lamented the terrible calamity that was befalling the Jews who were being shoved into ghettos as well as the suffering of Russian prisoners of war. He was very anxious about the persecution

\footnotetext{
$80 \quad$ Ibid., 127 .

81 Ibid., 129-30.

82 Helmuth James von Moltke, Letters to Freya 1939-1945 (New York: Knopf, 1990), 294 (letter of April 9, 1943). On König, see Roman Bleistein, "Lothar König, der 'Dritte Mann' der Jesuiten im Widerstand gegen den Nationalsozialismus," in Julius Oswald, ed., Schule des Denkens: 75 Jahre Philosophische Fakultät der Jesuiten in Pullach und München (Stuttgart: Kohlhammer, 2000), 41-58.
} 
of the Jews turning into a persecution of the Jesuits who were being regularly defamed by Nazi propaganda. ${ }^{83}$ Later in that same November a proposal for a letter from the churches was put forward and it explicitly wanted Protestants to join in the declaration so that Catholics could not be dismissed as a minority that was preaching defeatism on the home front. In order to protect from this type of charge, the public statement would not include mention of the treatment of Jews, Russian prisoners of war, or the atrocities being committed by Heinrich Himmler's (1900-45) men that a memorandum to the government would point out. ${ }^{84}$ In a letter to Rome in April, 1942, Rösch continues to express his anxiety about what the Nazis are preparing for the Jesuits now that their measures against the Jews are so clear with their removal and their "slaughter." ${ }^{85}$ In another report to Rome a year later, Rösch refers to sources that warn of extreme measures that will be taken against the Jesuits not just in Germany but in all the countries occupied by Germans. They face the same fate as the Jews, a "terrible campaign of physical destruction." Rösch mentions that, having contacted some bishops as well as the cardinals of Munich and Breslau, he asked if they would let the government know that they are aware of the planned measures and hint at their monstrosity. However, he goes on to say: "But, just between us, we have almost no hope that we will find much help because there has already been so much silence over the many terrible atrocities in Poland, Slovenia and Luxembourg, not to even mention those against the Jews and the Communists." 86

After the July 20, 1944 assassination attempt against Hitler, led by Claus Schenk von Stauffenberg (1907-44), Rösch went underground but was captured in January 1945 and imprisoned until the war's end. Still he survived and in a postwar reflection from 1945 or 1946, entitled "God's Grace in Fire and Flame," Rösch writes of his experience in the Moabit prison and his efforts to exercise a spiritual ministry for the prisoners. While there he meets a Jewish doctor from Poland who, out of concern that Rösch has been exposed to typhus, examines him and gives him medicine. Rösch sees in the meeting an encounter with God's care: "My God, now you even send me a doctor, in case I have been affected, and you send me a poor, Jewish doctor who could have no

83 "Rösch an Ledochowski" (November 5, 1941), in Kampf gegen den Nationalsozialismus, $105^{-16 .}$

84 "Stellungnahme aus dem Ausschuss für Ordensangelegenheiten" [after November 25, 1941], in Kampf gegen den Nationalsozialismus, 147-52.

85 "Rösch an Brust" (April 22, 1942), in ibid., 160-68, here 166.

86 "Rösch an Brust" (February, 1943), in ibid., 203-10, here 207. 
human hope to survive. ${ }^{\$ 7}$ And, of course, many others beside that doctor did not survive, including Rösch's subordinate, Delp whom Rösch had encouraged to work with von Moltke on social questions for the Kreisau Circle's post-Nazi planning, issues that had been Delp's special interest as an editor at the Jesuit review Stimmen der Zeit. Following the failed assassination attempt on Hitler's life, Delp was arrested with hundreds of others who were regarded as opponents of the Nazi regime. While he was in prison awaiting trial and execution, Delp continued his writing and much of what he wrote was smuggled out of prison and later published in such influential works as The Prison Meditations of Father Delp. ${ }^{88}$ These writings witness to an individual's courage in the face of impending death as well as to a profound grasp of the fundamental Christian message. A convert from Lutheranism, Delp seemed to have been liberated from identification with any narrow perception of Christianity, whether Protestant or Catholic. One of his biographers testifies to this advantage of a border-crosser which had given Delp a "breadth of vision that moved beyond the boundaries of Catholicism, and he regarded the Church as too parochial and inward-looking." ${ }^{89} \mathrm{He}$ was critical of the ecclesiastical silence of his day: "Has the Church forgotten 'Thou shalt not'? Has the Church forgotten the commandments, or is she keeping quiet because she is convinced that her clear and firm preaching is hopeless?"90 On New Year's night of 1945, just a month before his execution, Delp proclaimed a worldly faith:

The Church faces the same tasks that nations and states and the Western world in general have to face- the problem of humanity, how people are to be housed and fed and how they can be employed in order to support themselves. In other words, we need social and economic regeneration. And then human beings must be made aware of their true nature-in other words we need intellectual and religious regeneration. ${ }^{91}$

Delp interpreted his imprisonment and trial as primarily an assault upon Jesuits: for the Nazis a "Jesuit is and remains a degenerate." A "Jesuit commits a crime every time he draws a breath." His "crime was that of heresy against the

\footnotetext{
87 "Gottes Gnade in Feuer und Flamme," in ibid., 412-53, here 436.

88 With an introduction by Thomas Merton (New York: Macmillan, 1963). The original German edition was published in 1956 .

89 Mary Francis Coady, With Bound Hands: A Jesuit in Nazi Germany; The Life and Selected Prison Letters of Alfred Delp (Chicago: Loyola Press, 2003), 34.

$90 \quad$ Ibid., 34 .

91 Ibid., 140-41.
} 
Third Reich." ${ }^{92}$ Delp lamented the plight that von Moltke found himself in as a result of his association with the Jesuits and not because he was the influential leader of the Kreisau Circle. The irony of that situation was not lost on von Moltke himself and, in the final letters he wrote to his wife Freya before his execution, he identifies the reason for his death sentence not his own resistance activities as such but rather the Nazi hatred toward the Jesuits. "We are to die above all for St. Ignatius." ${ }^{\prime 93} \mathrm{He}$ tells his wife that, with the escape of Rösch and König, there were not enough Jesuits for a separate trial devoted to them and so Alfred Delp was joined to von Moltke's trial. He describes the proceedings before the judge of the People's Court, Roland Freiser (1893-1945), and the accusations of defeatism, conspiracy, and the preparation for the high treason in the July 20 attempt on Hitler's life. When Freiser asks about the discussions in Munich, von Moltke reports that "a storm of abuse came down on the Catholic clergy and the Jesuits: assent to tyrannicide-Mariana; illegitimate children; anti-German attitudes, etc., etc. ${ }^{94}$ When Freiser learned that Delp was not present for the talks that took place in his Munich quarters, he bellowed that that was "typically Jesuitical." Freiser addressed Delp: "By that very absence you show yourself that you knew exactly that high treason was afoot and that you would have liked to keep the tonsured little head, the consecrated holy man, out of it. Meanwhile he may have gone to church to pray that the conspiracy should succeed in a way pleasing to God."95 Attacking von Moltke for the discussions at his estate, Freiser points to what he regards as undeniable evidence for his criminality:

And who was there? A Jesuit Father! Of all people, a Jesuit Father! [...] Well all I can say is: now the fig leaf is off! A Jesuit Father, and with him of all people you discuss questions of civil disobedience! And you know the Jesuit Provincial too [Rösch]! He too was at Kreisau on one occasion! A Jesuit Provincial, one of the highest officials of Germany's most dangerous enemies, he visits Count Moltke in Kreisau! And you're not ashamed of it! No German would touch a Jesuit with a barge-pole! ${ }^{96}$

\footnotetext{
92 Ibid., 167, 179, 180 (two letters of January 11, 1945).

93 "Letter of January 10, 1945," in Letters to Freya 1939-1945, 405.

94 "Letter of January 10, 1945," in ibid., 400. The Jesuit Juan de Mariana (1536-1624) has been understood to declare tyrannicide justifiable in certain circumstances in his De rege et regis institutione (Toledo, 1599).

95 "Letter of January 10, 1945," in Letters to Freya 1939-1945, 400.

96 "Letter of January 10, 1945," in ibid., 402.
} 
Von Moltke, the Protestant, Lutheran Christian, son of Christian Scientists, reviews his death sentence for Freya: "But that I should die as a martyr for St. Ignatius of Loyola [...] is truly a joke, and I already tremble at the thought of Papi's paternal wrath, since he was always so anti-Catholic. The rest he will approve, but that?"97

Von Moltke was executed on January 23, 1945. Delp was hanged on February 2 , 1945. A visitor to the principal Berlin museum devoted to those who resisted National Socialism will find there a book of photos and documents entitled Jesuits and the Kreisau Circle. On the walls of that same museum are framed pictures of von Moltke, Rösch, König, and Delp. The Kreisau Circle would receive a more significant approval for what its participants had done and what its legacy was. In a 2007 address marking the one-hundredth anniversary of von Moltke's birth, the federal chancellor of Germany, Angela Merkel said: "The Kreisau Circle, as this resistance group later became known, was among the first to think consistently in European terms. They went beyond Germany in their thinking; they thought in terms of Europe. Their idea was that Germany would be part of a federative European state, a united Europe in which Christian morals and social reform should determine politics." 98

It would be misleading to leave the impression that these French and German Jesuits were representative of Jesuits in general. The more common attitude was more likely voiced in a recording by the Fortunoff Video Archive. The interviewee (Father John S.) had been a Jesuit studying in Hungary and one day he was walking by a railroad station and, while stealing a look through a hole in the fence, he saw a train packed with deportees:

I literally saw what you see in pictures, mothers with children, and people, and old people [...] and one man immediately jumped off, and I always remembered his face because he looked a little bit like my father [...]. I did not hear what he said to the German soldier [...] but his behavior was polite. What I made [missing something?] he was asking for water. And immediately that ss soldier with the club of his rifle clubbed him down, and several times, to insensitivity. Whether he died or was later put on the train [I don't know]. And then I ran away, I was so scared and I was so upset; I never saw anything like this in my life. I simply ran way.

97 "Letter of January 10, 1945," in ibid., 404. For a common study of both, see Elke Endraß, Gemeinsam gegen Hitler: Pater Alfred Delp und Helmuth James Graf von Moltke (Stuttgart: Kreuz, 2007).

98 "Address by Federal Chancellor Angela Merkel" (March 11, 2007). German Chancellery, Berlin. 
But he could not run away from what he had seen: "I see it personally as the greatest tragedy of my life that the Jewish people were deported all around me and I didn't do anything." ${ }^{\prime 99}$ In recalling the incident, he seems to blame himself for fleeing and imagines a different response if he witnessed the scene today: "Maybe I would call out." "At that time I was immobilized." "I was utterly unprepared." "I wish I could live my life [over]. Today perhaps I would be ready." "Today, maybe, I would be ready to then run in front of the train and lay down. Maybe I, I would have, today I would call out or protest or risk being shot down or clubbed down." ${ }^{100}$ How might we have prepared for confrontation with the violence of the Holocaust? It is a question for all moral agents since that period and, thus, also a question for Jesuits.

Fr. John S. would have had to overcome a particular Jesuit form of hostility toward Jews, which is asemitism. This is a non-violent indifference to Jews but one that finds consolation in their disappearance. This perspective has its root in an "original injustice," the policy of excluding those with Jewish ancestry from membership in the Jesuits even though such a program reversed its earliest distinctive commitment to their inclusion. When the Society of Jesus was founded, it would have been difficult to predict that such hostility would emerge. We know that Ignatius of Loyola's (c.1491-1556) desire for intimacy with his Savior even included an actual sharing in the Jewish lineage of Jesus and Mary. ${ }^{101} \mathrm{He}$ is reported to have criticized a Jewish convert for having failed to appreciate the gift of being born Jewish. Ignatius said he would want to be of Jewish ancestry because God chose this lineage for Jesus himself, becoming a "son of Abraham and David and other patriarchs and kings." 102 Ignatius's

99 Cited in Lawrence Langer, Holocaust Testimonies: The Ruins of Memory (New Haven: Yale University Press, 1991), 31.

100 These sentences are from the video in the Fortunoff Video Archive which can be accessed on You Tube at: www.youtube.com/course?list=ECE129969D102584DD (accessed January $22,2018)$.

101 See the citation from Ribadeneyra in James Reites, "St. Ignatius of Loyola and the Jews," Studies in the Spirituality of the Jesuits 13, no. 4 (September, 1981): 17. See also Thomas Cohen, "Jesuits and New Christians: The Contested Legacy of St. Ignatius," in Studies in the Spirituality of the Jesuits 42, no. 3 (Autumn, 2010): 3-5.

102 The testimony of Diego de Guzmán, cited in Robert A. Maryks, The Jesuit Order as a Synagogue of Jews: Jesuits of Jewish Ancestry and Purity-of-Blood Laws in the Early Society of Jesus (Leiden: Brill, 2010), 46. On the Jewish issue among the early Jesuits, see John W. O'Malley, The First Jesuits (Cambridge, MA: Harvard University Press, 1993), 188-92; Cohen, "Jesuits and New Christians: The Contested Legacy of St. Ignatius"; and more recently Marc Rastoin, Du même sang que Notre Seigneur:Juifs et jésuites aux débuts de la Compagnie (Montrouge: Bayard, 2011). 
devotion to the personal figure of Jesus saved him, and initially the Society, from a most common prejudice at that time, namely, the view that Jewish converts to Christianity and their descendants, the so called "New Christians" of Spain, were more Jewish than Christian, that their conversions were insincere and, thus, in the category of the time, they were of "impure blood." Such "tainted" ancestry justified their exclusion from church posts and religious orders. Ignatius courageously resisted ecclesiastical and political pressures and refused to exclude Jewish converts or their descendants from the Society's ranks and, thus, some of the most distinguished early Jesuits were of Jewish heritage with the result that the Society developed the reputation of being a nest or a synagogue of Jews. Ignatius was still very much a man of his times, however, and when it came to the matter of Jews who did not wish to become Christians, he could support the oppressive policy of ghettoization imposed by Pope Paul IV (r.155-59) in his 1555 Cum nimis absurdum. ${ }^{103}$ However severely we judge Ignatius on that matter, the Society was to abandon its founder's courageous policy on membership and would commit the "original injustice" that fueled future Jesuit hostility to Jews. In 1593, under pressure from ecclesiastical and secular as well as from its own members, the Society banned the admission of all with "Hebrew or Saracen stock." And not even the general of the order was allowed to dispense from this impediment of origin. The Fifth General Congregation explained: "For even though the Society, for the sake of the common good, wishes to become all things to all men in order to gain for Christ all those it can, still it is not necessary that it recruit its workers from any and all human races." ${ }^{104}$ The decree was adopted on December 23, 1593, "perhaps the most shameful day in Jesuit history" according to Fr. John Patrick Donnelly, S.J. ${ }^{105}$

The seventy years since the end of World War II has seen the Society of Jesus officially make efforts to overcome that shame. First was the abrogation of the 1593 prohibition on the admission into the Jesuits of any who are descended

103 Reites, "St. Ignatius of Loyola and the Jews," Studies in Jesuit Spirituality 13, no. 4 (1981): 13-17. For one critic, however, that display of Ignatius's social prejudice and theological supersessionism eviscerates Reites's benevolent interpretation of Ignatius's dealings with the Jews. See Eloise Rosenblatt, "Canonizing Edith Stein and Recognizing Catholic Antisemitism," in "Good News" after Auschwitz?: Christian Faith within a Post-Holocaust World, ed. Carol Rittner and John Roth (Macon, GA: Mercer University Press, 2001), 59-61.

104 Decree 52. English translation in For Matters of Greater Moment: The First Thirty Jesuit General Congregations, ed. John Padberg, S.J., et al. (St. Louis, MO: Institute of Jesuit Sources, 1994), 204.

105 John Patrick Donnelly, "Antonio Possevino and Jesuits of Jewish Ancestry," Archivum historicum Societatis Iesu 55 (1986): 3-31, here 8. 
from "Hebrew stock," which was interpreted as banning all Jews who had not been proven to descend from three generations of Christians. The 1946 General Congregation of the Jesuits adopted a decree abolishing the prohibition and its formulation is terse: it states that the "present congregation did not wish to retain it $[\ldots]$ but substituted for it a statement reminding the provincials [...] of the cautions to be exercised before admitting a candidate about whom there is some doubt as to the character of his hereditary background or his lack of Catholic education, raising the question whether he is suited for the life of the Society or is likely to persevere in it."106 There is no account of why the prohibition's targeting of those from Jewish ancestry was being lifted but several members of the congregation are noteworthy. De Lubac was an elected delegate from France to that congregation; the Belgian delegate Jean-Baptiste Janssens had been very effective in rescuing Jews during the war and he was to be honored later by Yad Vashem as one of the Righteous among the Nations. At this congregation Janssens himself was to be elected the leader of the Jesuits. A third name that stands out in the membership of this 1946 congregation is the Jesuit from Munich, Rösch, who had been a leader in the anti-Nazi German resistance. ${ }^{107}$ In addition to these individuals there had been petitions to the congregation from various sectors in the Society in Europe, America, and Asia that the ban be lifted because it was now perceived on the horizon of racism and anti-Semitism. Although there has still yet to be a public apology from the Society to the Jewish communities, Jesuits have become leaders in interreligious reconciliation.

\section{Conclusion}

What lessons might we take away from these rescuers and resisters? Even those who praise them often say that both the times and the individuals are so exceptional that all that one might do is bow to them as heroes. That is a tempting course because it would get most of us off the hook. And yet. And yet. As indicated earlier, only three per cent of the rescuers thought what they did was exceptional even though they risked their own lives and often those of their families most frequently for strangers. What I have come to understand is that the rescuers are not manifesting a polite modesty but they are affirming that they are ordinary men and women. "They affirm rather than transcend their

106 General Congregation 29 (1946), Decree 8, in For Matters of Greater Moment, 625.

107 See A. Rösch, Kampf gegen den Nationalsozialismus (Frankfurt: J. Knecht, 1985). 
humanity when performing their heroic actions."108 They live life as both a pilgrimage and an adventure. They teach us a lesson that we often forget: There need be nothing banal about being an ordinary human being. This is how one student of their rescue activities puts it: "Rescuers were heroic not so much because they overcame their fear and their drive to self-preservation-although this may be how we interpret their heroism - but because they had the wisdom to perceive correctly the responsibility that life had unexpectedly thrust upon them, and the courage actually to meet the demands of such responsibility."109 One of the Jesuits with whom I discussed Yad Vashem's honoring of him (Emile Planckaert [1906-2006]) said this to me when I asked him how he was able to do what he did in rescuing Jews even at the price of being tortured by the Gestapo: "What were you to do? A woman comes to your door and asks you to hide her children. You are going to hide them." We become better in coming to know these resisters, either in meeting them personally or reflecting on their deeds. As Paldiel puts it: "By identifying with the Righteous, we lay claim to the goodness in us, which is as inherently human as the other less pleasant manifestations in our behavior."110 And in doing that we touch the spiritual existence of one another and have entered a "divine milieu" where interreligious pluralism is a shared life and joy.

108 Andrew Michael Flescher, Heroes, Saints, \& Ordinary Morality (Washington, DC: Georgetown University Press, 2003), 154.

109 Ibid., 145.

110 Mordecai Paldiel, Sheltering the Jews (Minneapolis: Fortress Press, 1996), 202. 